\title{
FAMILY HOMESTEADS AND SUSTAINABLE DEVELOPMENT OF RURAL AREAS IN THE POST-COVID ERA
}

\author{
Oleg Chekmarev ${ }^{1}$, Doctor of economics/associate professor; Pavel Lukichev², Doctor of \\ economics/professor; Alexander Manilov³, senior lecturer \\ 1,3Saint-Petersburg State Agrarian University, Russia; ${ }^{2}$ Baltic State Technical University \\ "VOENMEH", Russia
}

\begin{abstract}
In recent decades, in the rural areas of Russia and some other states, a new form of land management family estates - has been developing. This form, without a legal status, has significant distinctive features from farms and horticultural associations. Family estates form entire settlements, functioning on the principles of preserving family values, master's motivation, cooperation, and environmental friendliness. Coronavirus crisis has exacerbated the desire of residents of large urban agglomerations to move to live in rural areas.

The authors investigate the features of the current state of management of the settlements of family estates and their prospects in the post-COVID period. The aim of the work is to assess the potential of family homesteads in the formation of conditions for sustainable development of rural areas. The paper assesses the current state and forms of economic activity of settlements of family estates based on the results of the survey authors (structured interviews).

The authors analyse the current and potential impact of family homesteads on sustainable rural development. The conclusion is made that under certain conditions, family estates can serve as one of the significant elements of the model of the future society in the post-COVID era.
\end{abstract}

Keywords: family estates, sustainable development, rural areas.

JEL code: Q56, R11, R23

\section{Introduction}

In the last decade of the XXI century, a new form of land management - family estates and settlements consisting of them-began to take shape on the territory of the former Soviet Union and some other countries of the world. It is required to study the potential of family homesteads in ensuring the sustainability of the development of rural areas and the impact on the development of cities. The basic hypothesis of the study is the provision that these forms of management in the future can become an important system-forming element of sustainable development of rural areas. Their formation will reduce the severity of the problems of depopulation of rural areas, increase economic activity and reduce environmental risks in rural areas, increase the efficiency of their interaction with urban agglomerations and labor markets.

Urban agglomerations, by sucking out personnel from the countryside like a vacuum cleaner, along with economic benefits, create a large population density, which contributes to the spread of pandemics like COVID-19. Pandemics occur in the XXI century are increasingly (Madhav, 2017; Fan, 2018). The large concentration of the population in urban agglomerations, plus the growing globalization associated with the increase in contacts between people from different countries and regions, give the effect of pandemics of the $21^{\text {st }}$ century. At the same time, the Internet and digital technologies enable a modern worker to work from anywhere on the planet, not just in urban agglomerations. Hence, there is a need for new forms of human settlement, such as family homesteads. According to Bollyky, pandemics were gradually disappearing, not because of vaccinations, but thanks to investments in sanitation and hygiene. Consequently, the sustainable development of the $21^{\text {st }}$ century, in the trinity of economic, social and environmental components, should focus on the resettlement of people, including the expansion of the number of family homesteads. 
The purpose of the study is to identify the potential and limiting factors of the formation of settlements consisting of ancestral estates as an element of ensuring the sustainability of the development of territories in the post-COVID era. To achieve this goal, the distinctive features of these forms of farming in rural areas will be considered on the basis of available statistical materials and data from surveys of representatives of ancestral estates. The article analyzes the relationship between the goals and elements of sustainable development and the potential for the formation of ancestral estates, taking into account the new challenges associated with the COVID-19 pandemic. The article examines the problems that limit the growth rate of family homesteads and possible measures of state regulation aimed at enhancing their development.

\section{Research results and discussion}

Family homesteads and settlements consisting of family homesteads represent an emerging type of small forms of farming on the land. Their differences from traditional forms of farming in rural areas in the form of personal subsidiary plots of the population, farms, summer cottages, farming within the framework of gardening partnerships are manifested in the totality of the features of the goals and methods of conducting their activities (Walker K. D., Plotnikova M., 2018; Chekmarev O. P., 2019).

The differences include:

- orientation to family values and the formation of a "place of procreation";

- maintaining a healthy lifestyle for members of family homesteads and the settlement as a whole;

- ecological orientation of agricultural production, the implementation of the principles of organic farming and the creation of balanced biogeocenoses within both an individual estate and in the settlement as a whole;

- the relatively large size of the land plots on which the estate is located (usually 1-2 hectares), in contrast to summer cottages, household and horticultural farms;

- striving for cooperation and mutual assistance of the members of the settlements;

- optional high level of marketability of agricultural production, in contrast to farms;

- a combination of different sources of income generation for members of the economy (agricultural production, self-employment in other areas of the economy, employment, etc.).

Thus, the listed features of ancestral estates largely overlap with the goals of sustainable development of territories, since they are aimed at simultaneously solving socio-economic and environmental problems of human activity. Therefore, it is advisable to understand in more detail the question of what is the current level of formation of family estates and what is their potential in creating conditions for sustainable development of territories. The sustainable development of territories will be considered not only from the standpoint of the well-known triad of balances of ecological, economic and social components of sustainable development (Medouz D., Randers J, Medouz D., 2007), but also by paying attention to other mandatory properties of sustainability. This is a reliance on development goals, which give the researcher the opportunity to assess the effectiveness of measures in the field of sustainable development of territories, and issues of the formation and disclosure of development potentials, and protective mechanisms that support the dynamic stability of territorial systems of sustainable development (Chekmarev O. P., 2018). It is also advisable to take into account a rather important aspect of the interconnectedness of sustainable development of rural and urban areas. The cities and countryside of any country or region are dependent on each other in a wide range of areas of interaction and resource allocation. Examples of this are the processes of labor force migration between the city and the countryside, cooperative ties of agricultural 
producers with suppliers of material and technical resources and buyers of agricultural products, the formation of transport and logistics corridors passing through rural areas, recreational and environmental protection functions of rural areas, educational and scientific potential cities and much, much more.

The COVID-19 pandemic has posed a new challenge to the global economy. It has intensified discussions on maintaining the sustainability of the development of socio-economic systems. This is especially true position of their protection from the effects of negative factors, restrictions must be imposed on the usual kinds of economic activity. These limitations were associated with the incidence rate of the new coronavirus infection. A review of primary statistical data provides contradictory estimates of the relationship between the level of population concentration in the territory and the proportion of infected people (Puzanov A. S., Bobrova K. V., 2020; Fang W., Wahba S., 2020). Within urban and adjacent areas, data contradicting the formal logic are noted, indicating a relatively large proportion of cases in urban areas and suburban areas with relatively lower population densities (Density and COVID-19 .., 2020). Coronavirus restrictions have exposed other problems that hinder the sustainable development of territories. First of all, these are the issues of maintaining the quality of life of the population in the context of falling production and the functioning of labor markets. The prevailing trend in the evolution of the labor market has become the spread of remote work and restrictions on migration flows of labor (Remote work ..., 2020; Ryazantsev S. V., Bragin A. D., Ryazantsev N. S., 2020).

The pandemic has created a new economic reality by changing the relationship between the values of life in urban and rural areas. Let's highlight two of its most striking features.

1. Telepresence distribution, as Mindell aptly defined, is a modern form of automation (Mindell D. A., 2015). This trend is long-term, as if the pandemic is over soon, many lost jobs will not recover, and the proportion of days worked at home will rise from $5 \%$ to COVID-19 to around $20 \%$, in line with the average desire of workers (Barrero J. M. et al, 2020). 2. Relocation of the most educated, successful professionals from urban agglomerations to the countryside, those, according to Paul Collier, constituted a new prosperous class - they are not capitalists and not traditional workers: they are educated people who have mastered new professions (Collier P., 2018).

In addition to the factors of the pandemic, other trends in their development are also affecting the development of rural areas, associated with the continuing increase in urbanization and a decrease in the amount of arable land in the overwhelming number of European countries and the group of economically developed countries (Tables 1, 2). 
The level of urbanization and changes in the rural population in selected countries of the world

\begin{tabular}{|l|c|c|c|c|}
\hline \multirow{2}{*}{ The country } & \multicolumn{3}{c|}{$\begin{array}{c}\text { Urbanization } \\
\text { rate, \%o }\end{array}$} & $\begin{array}{c}\text { Change in the rural population } \\
\text { in 2018 to 1995 / } \\
\text { thousand people }\end{array}$ \\
\cline { 2 - 4 } & $\mathbf{1 9 9 5}$ & $\mathbf{2 0 1 0}$ & $\mathbf{2 0 1 8}$ & -1229.8 \\
\hline Belarus & 68.4 & 75.1 & 78.6 & 158.0 \\
\hline Czechia & 74.6 & 73.3 & 73.5 & -18.9 \\
\hline Estonia & 70.3 & 68.1 & 68.0 & -164.3 \\
\hline Finland & 81.0 & 83.8 & 85.7 & -1854.6 \\
\hline France & 75.5 & 78.6 & 80.7 & -2515.0 \\
\hline Germany & 74.0 & 77.0 & 77.1 & -825.0 \\
\hline Hungary & 65.2 & 68.9 & 71.2 & -169.0 \\
\hline Latvia & 68.8 & 67.8 & 68.2 & -256.7 \\
\hline Lithuania & 67.3 & 66.8 & 69.5 & 413.1 \\
\hline Poland & 61.5 & 60.9 & 60.3 & -2678.8 \\
\hline Russian Federation & 73.4 & 73.5 & 73.5 & -2438.4 \\
\hline United States of America & 77.4 & 80.7 & 82.2 & \\
\hline
\end{tabular}

\section{Source: FAOSTAT}

The data in Table 1 indicate the ongoing process of urbanization and the increasing concentration of people living and working in urban agglomerations. This creates additional risks associated with the possibility of future spread of epidemics. The processes of urbanization, along with an increase in the concentration of the population in cities, reduce the population in rural areas. Of the countries considered in the table, only two (the Czech Republic and Poland) were able to increase the number of rural populations between 1995 and 2018. In other countries, more or less pronounced tendencies towards a decrease in the number of the rural population are observed. This decrease leads to various negative effects that threaten their sustainable development of territories, among which the following should be especially noted:

- the decline in the efficiency of social and economic infrastructure in rural areas (communication systems, education, health care, etc.), due to the fact that these objects have pronounced positive effects on the scale of detail;

- the living conditions of the rural population are deteriorating, business activity and incomes of the population are declining, and incentives for further outflow of the population to cities are increasing;

- a shortage of personnel is formed to ensure agricultural production and other traditional sectors of the economy in rural areas;

- depopulation of rural areas creates risks to the national security of states in connection with the threat of soft forms of seizure of territories by migrants, lack of control over territories;

- the number of labor force with valuable properties of economic motivation, responsibility, trust and other features that are actively formed earlier among the young rural population in connection with the specifics of residence and the need to maintain the multifunctionality of activities in rural areas is decreasing; 
- cities are deprived of a source of replenishment of the labor market with motivated and nationally identical labor resources. what causes the need for a cross-border influx of labor and the strengthening of the problems of relations between migrants and the indigenous population (Lukichev P. M., 2021);

- replacing the labor force with technical and robotic systems can provoke the intensification of agriculture, the concentration of production and the aggravation of environmental problems of land use in rural areas (depletion of soil fertility, the formation of volumes of animal waste. which cannot be effectively used in the territories nearby to the livestock complexes, etc.).

The development of family estates requires the availability of land for their formation. The potential of land areas is available in many countries. We will consider it on the basis of a study of the dynamics of only the arable lands most adapted for the formation of family estates. Although, of course the nature of the activities of these estates allows to allocate land for their formation and from other areas (such as meadows, pastures, forest).

Trends in the decrease in the amount of arable land in the countries under consideration are shown in Table. 2.

Table 2

Dynamics of changes in the area of arable land in some countries, thousand hectares

\begin{tabular}{|l|c|c|c|c|c|c|}
\hline \multicolumn{1}{|c|}{ The country } & $\mathbf{1 9 9 2}$ & $\mathbf{2 0 0 0}$ & $\mathbf{2 0 1 0}$ & $\mathbf{2 0 1 8}$ & $\begin{array}{c}\mathbf{2 0 1 8} \\
\mathbf{1 9 9 2}\end{array}$ & $\begin{array}{c}\text { \% of Iost arable } \\
\text { land from the } \\
\text { total area } \\
\text { of 2018 }\end{array}$ \\
\hline Belarus & & & & & 6.5 \\
\hline Czechia & 6084 & 6133 & 5535 & 5712 & -372 & 34.1 \\
\hline Estonia & - & 3243 & 3171 & 2484 & -848 & 62.1 \\
\hline Finland & 1115 & 843 & 645 & 688 & -427 & 1.8 \\
\hline France & 2284 & 2188 & 2254.8 & 2244 & -40 & 1.3 \\
\hline Germany & 17847 & 18354 & 18301 & 18126 & $-228 *$ & 0.6 \\
\hline Hungary & 11467 & 11804 & 11846 & 11731 & $-73 *$ & 9.7 \\
\hline Latvia & 4742 & 4602 & 4392 & 4324 & -418 & 30.3 \\
\hline Lithuania & 1688 & 970 & 1173 & 1295 & -393 & 36.4 \\
\hline Poland & 2885 & 2878 & 2127 & 2115 & -770 & 30.2 \\
\hline Russian Federation & 14337 & 13993 & 10829 & 11009 & -3328 & 8.5 \\
\hline United States of America & 132008 & 124374 & 121649 & 121649 & -10359 & 16.7 \\
\hline
\end{tabular}

\section{Source: FAOSTAT}

A decrease in arable area is a fairly pronounced trend in all countries considered in the table. In general, it can be seen that both in the countries of Eastern Europe and in the developed countries of the world there is a tendency to a decrease in the area of arable land, which creates the potential for family homesteads as a factor in eliminating the depopulation of rural areas. This potential is especially high in the Baltic countries, the Czech Republic, Poland, the USA and the Russian Federation. Now, in the period of the COVID-19 pandemic and the heyday of remote employment (telepresence according to Mindell D. A., 2015), there are new opportunities for the relocation of economically active, educated workers to rural areas. 
Now let's return to the issue of the impact of the pandemic on the sustainability of the development of rural areas. Almost all studies show that rural areas, as located at a distance from the primary foci of infection, have a slower development of the epidemic relative to urban agglomerations (Puzanov A. S., Bobrova K. V., 2020; Healy D., at all, 2020). The peak of the incidence appears with a significant lag from the latter. This creates a reserve of time for the adaptation of the health care system to the conditions of the pandemic, creates opportunities for the adaptation of the health care system to the new situation. This is a factor in smoothing out the consequences of the disease, reducing the mortality rate. The study of the statistics of the incidence rate in the Leningrad region of the Russian Federation shows that the incidence rate in rural settlements for almost a year of the epidemic is statistically significantly lower than in regional centers and urban areas as a whole (Table 3 ).

Table 3

The incidence rate in urban and rural areas of the Leningrad region, people per 1000 inhabitants 2020-2021

\begin{tabular}{|c|c|c|c|}
\hline Districts & $\begin{array}{c}\text { Urban } \\
\text { settlements }\end{array}$ & $\begin{array}{c}\text { Rural } \\
\text { settlements }\end{array}$ & $\begin{array}{l}\text { District } \\
\text { centers }\end{array}$ \\
\hline Leningrad region & 20.09 & 17.60 & 26.56 \\
\hline Boksitogorsk municipal district & 24.96 & 15.76 & 31.74 \\
\hline Volosovsky municipal district & 24.86 & 20.13 & 24.86 \\
\hline Volkhov municipal district & 15.66 & 12.17 & 15.21 \\
\hline Vsevolozhsk municipal district & 18.54 & 16.95 & 24.41 \\
\hline Vyborg municipal district & 20.71 & 12.50 & 26.32 \\
\hline Gatchina municipal district & 22.62 & 20.24 & 24.06 \\
\hline Kingiseppsky municipal district & 19.78 & 13.53 & 20.15 \\
\hline Kirishi municipal district & 32.29 & 20.50 & 32.80 \\
\hline Kirovsky municipal district & 13.83 & 12.47 & 16.59 \\
\hline Lodeynopolsky municipal district & 40.44 & 19.27 & 40.97 \\
\hline Lomonosov municipal district & 16.08 & 17.67 & 19.75 \\
\hline Luga municipal district & 21.43 & 19.76 & 21.61 \\
\hline Podporozhsky municipal district & 30.41 & 40.39 & 32.08 \\
\hline Priozersky municipal district & 39.95 & 22.72 & 42.78 \\
\hline Slantsevsky municipal district & 30.56 & 16.29 & 30.56 \\
\hline Tikhvin municipal district & 28.75 & 26.89 & 28.75 \\
\hline Tosno Municipal District & 14.38 & 14.56 & 18.87 \\
\hline Average & 24.43 & 18.93 & 26.56 \\
\hline
\end{tabular}

* - compared to 2000.

\section{Source: Rosstat; The total number of registered ..., 2021}

Statistical data on people living in rural and urban settlements were obtained from the Rosstat database, and the incidence rate from data from the regional body of Rospotrebnadzor. To compare the number of COVID cases in urban and rural areas, a relative indicator was taken - the number of cases per thousand people, which averaged: 18.93 in rural areas, 26.56 in regional centers and 24.43 in cities. The assessment of the significance of the differences in the sample averages for the Student's t-test showed that the discrepancies are significant for rural areas and cities (tfact $=2.11$ versus tcrit $=2.04$ ), as well as for rural areas and regional centers (tfact $=3.01$ versus tcrit $=2.04$ ) with 5 - the percentage level of significance 
and 32 degrees of freedom, which confirms the influence of the place of residence on the incidence rate. This is also confirmed by the empirical correlation calculated on the basis of the variance addition rule: between the number of cases per thousand of the population and the location of cases. There is a moderate statistical relationship (number of cases and residence in urban / rural areas - 0.35, number of cases and residence in district centers / rura areas - 0.47).

Thus, in contrast to the previous studies, when assessing the structure of the incidence rate based on the division of rural and urban areas, the hypothesis of less prevalent COVID-19 in rural areas was confirmed. The reasons for the discrepancy are assumed to be related to the fact that studies in China and the United States were aimed at a general delineation of territories with a predominantly rural and urban settlement, but they did not take into account the division of the number of cases within these territories. In predominantly rural areas, there are urban settlements in which significant incidence rates may exist. Some deviations from the general dependence, identified on the basis of the study of the Leningrad region, partly confirm this assumption. So, the only area where there is a significantly higher incidence rate in rural areas relative to urban areas is Podporozhsky. However, a detailed study of the reasons for this phenomenon shows that the increase in the percentage of cases was provided only by one settlement in the village of Vinnitsa. It is very close to the category of urban-type settlements in terms of the number of inhabitants (more than 2 thousand people). If we do not take into account the outbreak of morbidity in this village, then the statistics for the Podporozhsky district as a whole will fully fit into the general trend. Low differences between the incidence in urban and rural areas are also observed in those areas that are in close proximity to St. Petersburg and have a significant degree of intra-district urbanization. This also confirms the conclusions of foreign studies that with wide pendulum migration, more dispersed areas of settlement may be exposed to greater risks of spreading infections due to the specifics of employment conditions and population movements. In general, rural areas of the Leningrad region show a higher resistance to the spread of the disease.

Of course, we are not dealing with a pure experiment, and the research results could be influenced by the peculiarities of the practice of statistical registration of sick people in rural and urban areas, as well as other factors, for example, the propensity to seek medical help, its availability for the population. However, the same problems should be taken into account in alternative studies of foreign analysts. Therefore, at the current stage of the analysis, we can say that with the existing registration system in the Leningrad Region, significant differences were found between the incidence rate of COVID-19 in urban and rural areas with a downward trend in the percentage of cases along the line: regional center - urban settlements of the region - rural settlement. The moderate level of this relationship is quite understandable due to the presence of multiple other factors affecting the spread of infection, which reflects the overall complexity of modeling socio-economic processes. For more unambiguous conclusions, more extensive research is required, including at the level of other regions of the country.

Thus, the intermediate conclusions suggest that the development of rural forms of settlement is an important component of the sustainable development of not only rural areas but also urban agglomerations. Now it is necessary to analyze the current and potential role of family estates in this process.

Table 4 presents the main statistical characteristics of family homesteads, mainly of the Russian Federation, obtained on the basis of studying the database of family homesteads and settlements of them, which are available in the public domain (Eco-settlements, family homesteads..., 2021).

Before analyzing the data shown in the table, it is necessary to make a few comments on the content of the database on the basis of which they were calculated. First, not all settlements contained in the database have up-to-date and complete information, which reduces the accuracy of estimates of 
aggregated indicators. The database on estates abroad in Russia is rather weak and makes it possible to speak with confidence about the presence of developed settlements, consisting of family estates only in Ukraine, and then in an extremely limited number (4 settlements). Note that according to Walker K. D., Plotnikova M. (2018), there are much more family homesteads in Ukraine. Nevertheless, a fairly large list of settlements and the allocation of the category of developed settlements (in which more than 10 people permanently live) within them, makes it possible to identify general trends in their development. Although, for more accurate research, it is necessary to update the existing information base.

In Table 4, a developed settlement of family homesteads is understood as a settlement in which more than 10 people live on a year-round basis. Other categories of settlements presented in the sample are groups of "wintering" estates (in which there are families permanently residing in them), settlements under construction, taking shape, and settlements for which initiative groups work to allocate land for their arrangement.

Table 4

Separate characteristics of family homesteads and settlements

\begin{tabular}{|l|c|}
\hline \multicolumn{1}{|c|}{ Characteristics } & Numerical indicator \\
\hline Total number of settlements / including in Russia & $522 / 435$ \\
\hline $\begin{array}{l}\text { Regional representation, Russia (number of regions) total / with developed } \\
\text { settlements }\end{array}$ & $15 / 4$ \\
\hline Country representation (of countries). total / with developed settlements & $15 / 34$ \\
\hline Average number of estates in a settlement, total /in a developed settlement & $43 / 93$ \\
\hline Average number of people in a settlement, total /in a developed settlement & $9 / 18$ \\
\hline $\begin{array}{l}\text { Average number of families in a settlement living on a year-round basis, total } \\
\text { in a developed settlement }\end{array}$ & $26 / 52$ \\
\hline $\begin{array}{l}\text { Average number of people in a settlement living on a year-round basis, total / } \\
\text { in a developed settlement }\end{array}$ & $2.75 / 2.84$ \\
\hline $\begin{array}{l}\text { Average household size in a settlement, total / from the group of developed } \\
\text { settlements, people }\end{array}$ & $13,8 / 33,0$ \\
\hline $\begin{array}{l}\text { The share of developed settlements / settlements in which at least one family } \\
\text { permanently resides, in \% of the total number of settlements }\end{array}$ & 1.19 \\
\hline $\begin{array}{l}\text { Average size of an estate in a group of developed settlements, ha } * \\
\text { The possibility of building a residential building on the land of the estate with } \\
\text { the right of registration / without the right of registration in \% of the total } \\
\text { number of settlements }\end{array}$ & $38,5 / 13,2$ \\
\hline - excluding five settlements with large areas (10-50 ha / settlement). & \\
\hline
\end{tabular}

Source: author's calculations on Eco-settlements, tribal settlements ..., 2021

The results of the analysis of the statistics of family estates and settlements (Table 4) allow us to draw the following conclusions:

- the greatest distribution and development of settlements consisting of ancestral estates is characteristic of Russia. this is due to the fact that it was here that the basic principles of both formation and functioning were born;

- the total number of people living in the family estates of Russia. the number of people included in the database can be conditionally estimated at 18-20 thousand people, which is not a significant value today and is about $0.05 \%$ of the total rural population of the country; 
- a significant number of ancestral estates are at the stage of formation, but almost half of the settlements have families permanently residing on their territory, and $13.8 \%$ of the settlements have a significant group of households on a year-round basis;

- the average size of land plots assigned to an estate is 1.19 hectares, which generally corresponds to the basic characteristics of this form of farming, which were noted above, although in remote regions this area can increase significantly (10-50 hectares / estate);

- the characteristics of developed settlements make it possible to consider them as small centers of economic activity in rural areas, which can play the role of central places (according to Walter Kristalller's theory) of a lower level than villages and settlements where municipal authorities are located;

- the average household size in developed settlements is slightly higher than that in rural areas as a whole and significantly higher than the average household size in urban areas (2.84 versus 2.5 people/family in urban agglomerations (Rosstat)). this confirms the provision on the priority of family values of the residents of the settlements.

The results of the survey of representatives of family homesteads, kindly provided by the authors of the Public Chamber Chairman Committee on Agrarian Issues of the State Duma of the Russian Federation on Agriculture and personally Samokhina I. N., as well as the results of interviews with the heads of family homesteads, conducted by the authors, can not only prove the correctness of the above at the beginning of the work of the distinctive features of family estates, but also to reveal the problems of their development. As part of the survey, information was collected on the functioning of 32 settlements, consisting of family homesteads of 12 regions of Russia. The main problems most often mentioned by the respondents are the following:

- the lack of a legal status of a family estate and a settlement consisting of family homesteads, which makes the settlements look for surrogate mechanisms for the legal legitimization of their existence and complicates the possibilities of active development within the framework of basic goals;

- restrictions on the construction of housing on agricultural land restricts the possibilities of permanent residence within settlements;

- difficulties with ensuring the supply of infrastructure objects to settlements (electricity, gas, communications, roads, etc.), while as a rule, the internal infrastructure of the settlement is provided at the expense of its members ' own resources through cooperation.

Settlements consisting of family homesteads are widely represented on the territory of the Russian Federation. At the same time, the pace of formation and development of family homesteads does not yet make it possible to talk about the mass nature of their functioning, which is associated with the problems that will be discussed below.

The interview also shows the actual activity of settlements in the field of ensuring the environmental safety of living, the formation of sustainable agrobiocenoses on the territory of estates and settlements. The cases of Yaroslavl, Vladimir, and some other regions of Russia demonstrate that settlements can play a significant role in recreating natural landscapes, increasing soil fertility and ensuring their water balance, etc. In addition, as a result of the interview, the wide spread of the multidisciplinary nature of the sources of income of family estates was confirmed. At the same time, most of the members of settlements receive the bulk of their income, conducting economic or labor activities in cities. Thus, rural areas receive an inflow of expenditures, the source of income of which is urban agglomerations. 
Assessing the potential for the development of family homesteads and their settlements from the point of view of the possibilities of accommodating a part of the employed population, which can be transferred to a remote mode of work in the Russian Federation, the possibilities of resettlement to family homesteads of up to 29 million people were identified, incl. at least 11 million employed population. The calculations were based on the average land area of an estate of 1 hectare, an average household size of 2.6 people, and the use of only the area of unused arable land for the formation of family estates (other sources of the potential for expanding estates were not taken into account). Using the forecasts of McKinsey \& Company on the possibilities of transferring workers to remote work in certain sectors of the economy (McKinsey \& Company, 2020) and applying them to the structure of employment in Russia (Rosstat), the authors calculated the potential number of remote workers, which amounted to more than 16 million people. ... in general for the Russian Federation. Thus, even a partial achievement of the noted levels of resettlement, remotely employed in family estates, makes it possible to locate a significant number of remote workers in rural areas and significantly increase the population of rural areas. If we compare these figures with the data on the request of the townspeople for resettlement to the countryside (Zvyagintsev V. I., Neuvazhaeva M. A., 2015), then we can conclude that obtaining the noted results is quite achievable. This will require a set of measures of state regulation to solve the previously listed problems that limit the possibilities for the development of family homesteads settlements.

\section{Conclusions, proposals, recommendations}

1) Family estates and settlements consisting of them are a promising form of farming in the countryside for solving the problems of sustainable development of not only rural areas, but also cities. Their benefits are amplified in the face of the COVID-19 pandemic.

2) On the basis of statistical data for the Leningrad Region, the existence of significant differences in the level of the pandemic spread in rural, urban settlements and regional centers has been proved. The lower morbidity rate in rural areas enhances the feasibility of reducing the level of urbanization of the Russian economy. Other advantages of this process are the reduction of the severity of the country's demographic problems, the provision of the labor market with human capital with high indicators of manifestation of the values of trust, economic motivation, and responsibility typical of rural residents.

3) Sustainable development of rural areas and cities are interrelated and cannot be considered in isolation from each other.

4) The potential for the development of family homesteads is provided by the availability of land, the possibility of remote work in rural areas in the interests of urban agglomerations, as well as the existence of a request for the resettlement of townspeople in the countryside.

5) A similar potential for the development of family homesteads is characteristic not only for Russia, but also for many economically developed states.

6) The development of family homesteads is constrained by the lack of a legal status of this form of management, restrictions on the use of land for the development of estates and general problems of infrastructure development in rural areas. Without solving these problems within the framework of state regulation, family estates will not be able to reveal their potential in solving the problems of sustainable development of territories.

\section{Bibliography}

1. Barrero, J. M., Bloom, N., \& Davis, S. J. (2020). COVID-19 Is Also a Reallocation Shock. NBER Working Paper No. 27137. National Bureau of Economic Research. Retrieved: https://doi.org/10.3386/w27137 Access:

16.01.2021 
2. Bollyky T. (2018). Plagues and the Paradox of Progress. Why the World Is Getting Healthier in Worrisome Ways. Cambridge, MA. MIT Press. 2018. - 253 pages.

3. Brown J. von, Mirzabaev A. (2016). Izmenenie zemlepol'zovaniya i ekonomika degradacii zemel'nyh resursov v Baltijskom regione (Land use change and the economics of land degradation in the Baltic region). Baltic Region. Vol. 8, No. 3. pp. 45-60. DOI: 10.5922 / 2074-9848-2016-3-3.

4. Chekmarev O.P. (2019). Potencial rodovyh pomestij v ustojchivom razvitii sel'skih territorij (The potential of family homesteads in the sustainable development of rural areas). Proceedings of the International Academy of Agrarian Education. No. 46. pp. 158-161.

5. Chekmarev O.P. (2018). Metodologicheskie osnovy koncepcii ustojchivogo razvitiya: miro-, makro- i global'nyj uroven'. (Methodological foundations of the concept of sustainable development: world. Macro and global level). Proceedings of the St. Petersburg State Agrarian University. No. 50, pp. 135-140.

6. Collier, P. (2018) The Future of Capitalism: Facing the New Anxieties. London. Pinguin Kindle Edition. - pp. 1056.

7. Coronavirus Was Slow to Spread to Rural America. Not Anymore. By Jack Healy, Sabrina Tavernise, Robert Gebeloff and Weiyi CaiApril 8, 2020 New York Times database of cases and deaths, based on data from state and local health agencies, hospitals and the Centers for Disease Control and Prevention (county-level cases and deaths); United States Department of Agriculture's Economic Research Service (urban and rural classifications); 2014-18 American Community Survey (population data). Data is as of April 6, 2020. Retrieved: https://www.nytimes.com/interactive/2020/04/08/us/coronavirus-rural-america-cases.html Access: 01.03 .2021

8. Density and COVID-19 in New York. Citizens Housing and Planning Council, 05.2020 [online]. Retrieved: https://chpcny.org/wp-content/uploads/2020/05/CHPC-Density-COVID19-in-NYC.pdf Access: 01.03.2021

9. Ekoposeleniya, rodovye poseleniya, rodovye pomest'ya. Poisk rodovogo poseleniya (ekoposeleniya). (Ecosettlements, family settlements, family estates. Search for a tribal settlement (ecovillage)). Retrieved: http://poselenia.ru/search-rp Access: 01.03.2021

10. Fan, Y. Y., Jamison, D. T., \& Summers, L. H. (2018). Pandemic risk: how large are the expected losses? Bulletin of the World Health Organization, Vol.96(2), p.129-134. https://doi.org/10.2471/BLT.17.199588

11. Fang, W., Wahba, S. Urban Density is not an Enemy in the Coronavirus Fight: Evidence from China. World Bank Blog, 20.04.2020. Retrieved: https://blogs.worldbank.org/sustainablecities/urban-density-not-enemycoronavirus-fight-evidence-china Access: 01.03.2021

12. FAOSTAT Land Use. Retrieved: http://www.fao.org/faostat/en/\#data/RL Access: 28.02.2021

13. Lukichev, P.M. Labor market of the future. - SPB .: POLITECH-PRESS, 2021 .-pp. 61-74.

14. Madhav, N., Oppenheim, B., Gallivan, M., et al. Pandemics: Risks, Impacts, and Mitigation. In: Disease Control Priorities: Improving Health and Reducing Poverty. 3rd ed. The International Bank for Reconstruction and Development / The World Bank, Washington (DC); 2017, p. 29.

15. McKinsey \& Company. (2020) What's next for remote work: An analysis of 2,000 tasks, 800 jobs, and nine countries. Retrieved: https://www.mckinsey.com/featured-insights/future-of-work/whats-next-for-remotework-an-analysis-of-2000-tasks-800-jobs-and-nine-countries\# Access: 01.03.2021

16. Medouz, D., Randers, J, Medouz, D. (2007). Predely rosta. 30 let spustja (Growth limits. 30 years later). - M.: IKC «Akademkniga. - 342 p.

17. Mindell, D.A. 2015. Our Robots, Ourselves: Robotics and the Myths of Autonomy, New York, NY. Viking. - p. 16.

18. Puzanov A.S., Bobrova K.V. (2021) Goroda na perednej linii bor'by s koronavirusom - obzor mezhdunarodnoj ekspertnoj povestki i ocenka ee adekvatnosti rossijskim realiyam. (Cities on the front line of the fight against coronavirus - an overview of the international expert agenda and an assessment of its adequacy to Russian realities). Institute for Urban Economics [online]. Retrieved:

http://www.urbaneconomics.ru/research/mind/goroda-na-peredney-linii-borby-s-koronavirusom-obzormezhdunarodnoy-ekspertnoy Access: 01.03.2021

19. Remote Work Trends. WWR [online]. Retrieved: https://weworkremotely.com/remote-work-trends Access: 01.03 .2021

20. Remote Working in the COVID-19 Pandemic: A Guide for Employers. Geneva: International Labor Office, 2020 [online]. Retrieved: https://www.ilo.org/wcmsp5/groups/public/---ed_dialogue/--act_emp/documents/publication/wcms_749872.pdf Access: 01.03.2021

21. Rosstat. Official site. Retrieved: http://www.gks.ru Access: 28.02.2021.

22. The total number of registered cases of COVID-2019 in the Leningrad Region from 13.04.2020 to 01.03.2021. Department of the Federal Service for Supervision of Consumer Rights Protection and Human Welfare in the Leningrad Region [online]. Retrieved: http://47.rospotrebnadzor.ru/content/total-number-registered-covid2019-in-the-territory-Leningrad-region-is-1 Access: 01.03.2021

23. Ryazantsev, S.V., Bragin, A.D., Ryazantsev, N.S. Polozhenie trudovyh migrantov v regionah mira: vyzovy pandemii COVID-19 i reakciya pravitel'stv (The Situation of Labor Migrants in Regions of the World: Challenges of the COVID-19 Pandemic and Government Responses). Scientific Review. Series 1: Economics and Law. 2020. No. 3. P. 7-21

24. Walker, K. D., Plotnikova, M. Ecological settlement as a self-government model in rural areas. Management Theory and Studies. For Rural Business and Infrastructure Development. 2018. Vol. 40. No. 3. pp. 416-423.

25. Zvyagintsev V.I., Neuvazhaeva M.A. (2015). Pereselency iz goroda v sel'skuyu mestnost': fenomen «obratnoj migracii» $v$ sovremennoj Rossii (Migrants from the city to the countryside: the phenomenon of "reverse 
Proceedings of the 2021 International Conference "ECONOMIC SCIENCE FOR RURAL DEVELOPMENT" Jelgava, LLU ESAF, 11-14 May 2021, pp. 90-101 DOI: $10.22616 / E S R D .2021 .55 .009$

migration" in modern Russia). World of Russia. No. 1. - S. 101-135. Retrieved:

http://cyberleninka.ru/article/n/pereselentsy-iz-goroda-v-selskuyu-mestnost-fenomen-obratnoy-migratsii-vsovremennoy-rossii Access: 02.03.2021 